 \\ International Journal of Social Sciences and Management
}

\section{A Rapid Publishing Journal}

ISSN 2091-2986

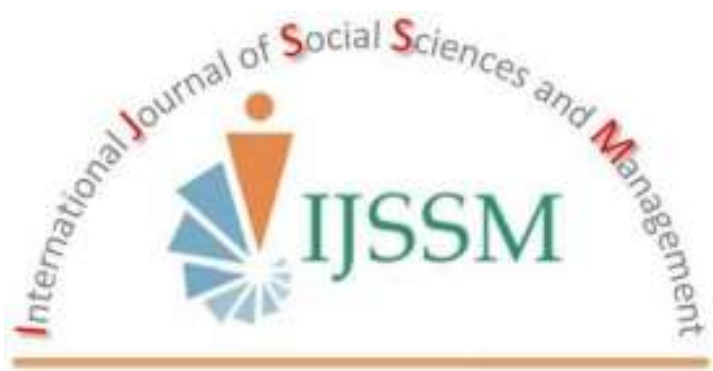

\section{Indexing and Abstracting}

CrossRef, Google Scholar, International Society of Universal Research in Sciences (EyeSource), Journal TOCs, New Jour, Scientific Indexing Services, InfoBase Index, Open Academic Journals Index (OAJI), Scholarsteer, Jour Informatics, Directory of Research Journals Indexing (DRJI), International Society for Research Activity (ISRA): Journal Impact Factor (JIF), Simon Fraser University Library, etc.

Vol- 2(4), October 2015 


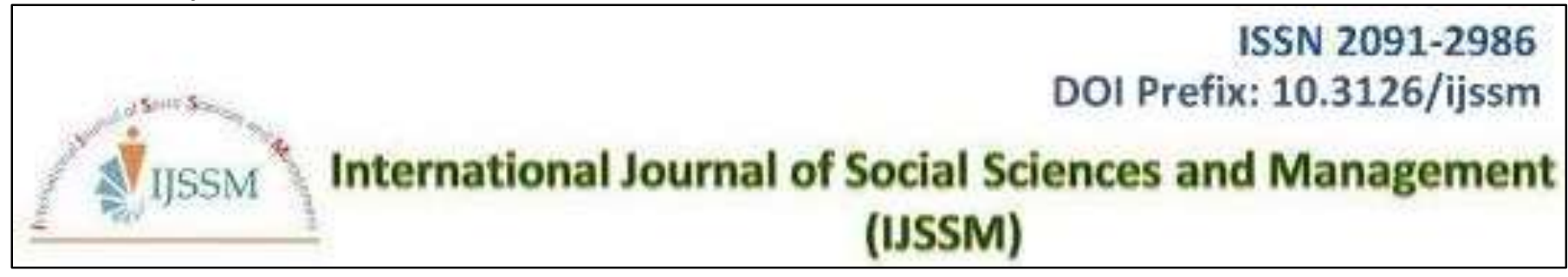

Research Article

\title{
ELUCIDATION OF THE SOCIO -POLITICAL CONSTRUCT OF RURAL LEADERS: AN AGRO- ECONOMIC AND SOCIO- POLITICAL DISCOURSE
}

\author{
Sabita Mondal ${ }^{1}$, MM Adhikary ${ }^{2}$, Ridip Ranjan Saharia ${ }^{3}$ and Babli Dutta ${ }^{4}$ \\ ${ }^{1}$ Department of Agricultural Extension, Uttar Banga Krishi Vishwavidyalaya, Faculty of Agriculture, Agricultural Extension, Pundibari, Cooch Behar, PIN- \\ 736165, West Bengal, India. \\ ${ }^{2}$ Department of Agricultural Extension, Bidhan Chandra Krishi Vishwavidyalaya, Faculty of Agriculture, Agricultural Extension, Mohanpur, Nadia, PIN- \\ 741252, West Bengal, India \\ ${ }^{3}$ Krishi Vigyan Kendra, Cachar, Assam Agricultural University, Arunachal-788025, Assam \\ ${ }^{4}$ Department of Plantation Crops and Processing, Uttar Banga Krishi Vishwavidyalaya, Faculty of Horticulture, Agricultural Extension, Pundibari, Cooch \\ Behar, PIN-736165, West Bengal, India. \\ *Corresponding author's email: sabidas_2007@rediffmail.com
}

\begin{abstract}
Modern leadership has permeated the village social system. Change within that system will naturally necessitate a change in the socio -political construct of the leaders. The socio-political construct of a leader has been the resultant of interactive perception and perceptual configuration. In developing countries like India, leaders act as a change agent so far as development of villages and villagers are concerned. It is very important for the leaders to have a modern outlook as well as to be democratically oriented if they have to work in a democratic set up as India claims to be for a sustainable and renewable development of India. The study has been conducted mainly to estimate the socio political structure of the rural leaders as a predicted character in elucidating the leadership dynamics in a given social ecology. Accordingly, 19 different independent variables were included in designing socio-political structure. The present study was carried out with a sample of 100 rural leaders (sociometric leaders and institutional leaders) at Haringhata block I of Nadia district in the state of West Bengal. The purposive as well as simple random sampling and systematic sampling techniques were adopted for the present study. It has been found that the variables like Occupation (X3), Education (X4), Five Year Plan (X7), Panchayat system perception (X8), Dominance (X9), Self-confidence (X10), Dogmatism (X11), Authoritarianism-equilitarianism (X12), Conservatism-liberalism (X13), Fatalism- scienticism (X14), Individualism familism (X15), progressive-reactionary (X16), Political ideology (X17), Election perception (X18), and alienation (X19) have contributed immensely towards profiling the political structure of the rural leaders. Thus the whole of the study rightly has come out with a clear indication that for better and effective construction of leadership and unleashing of their function, we need to have a focused and effective training viz a viz motivational interventions.
\end{abstract}

Keywords: Leadership; Leadership structure; Leadership function; Political construct of leaders; Rural leadership; Social structure of leaders; Socio-political construct

\section{Introduction}

Leadership has been the ability and potentiality to steer and influence the decision and action of others. It is a creative humanity for changing and shaping the behaviour of others as well as of surroundings in a desired direction. It is an alternative way of grooming people's mind and body to bring about constructive change in the society.

The state of West Bengal after the introduction of Panchayati Raj and having a profile of socio- political revolution through land reforms and Burga movements has been bestowed with diverse leadership pattern and with a genre of people's leadership. The leadership is considered to be important in agricultural development under "modernization" paradigm and transfer of technology model and an essential ingredient for achieving sustainable agriculture (Zamani and Karami, 2006)
The style of leadership is a dynamic and constantly changing phenomenon, varying greatly according to the context in which it develops (Singh, 1991). The average leaders are democratically minded, but not politically oriented towards a particular political ideology. They feel they are not politically effective and suffer from anomie from the political point of view (Adhikary, 1982).

\section{Objectives}

1) To estimate the socio political structure of the rural leaders as a predicted character in elucidating the leadership dynamics in a given social ecology.

2) To estimate the agro-economic, socio psychological and situational factors as the set of predictors to estimate the socio political structure of the rural leaders as a predicted character. 
3) To evaluate the interactive and directional characters of both the predictor and predicted character as operating and performing in the given social ecology.

\section{Materials and Methods}

The present study was carried out with the rural leaders (sociometric leaders and institutional leaders) at Haringhata Block I of Nadia district in the state of West Bengal. The purposive sampling technique was followed in case of selecting the state, district, block and villages for generating the required data. From three villages namely Simhat, Fatepur and Mollabellia 100 respondents were selected. For some leaders selection have been must since there has been no choice but to select for example Panchayat leaders for some respondents the researcher has to opt for random sampling approaches since, some few have been selected out of relatively larger population.

Initially a pilot study was conducted to understand the area, its people, institutions and structure and functions of the rural leaders as well as their contribution towards the agro - economic development.

The data were collected with the help of structured schedule through personal interview methods and then the collected data were processed into statistical analysis like correlation of coefficient, multiple regression analysis and path analysis.

\section{Results}

The classical outlook of clubbing the variables into causal and consequent one's has got some intrinsic problem, especially in social sciences. Sometimes the demarcation between causal and consequent variables is rendered not only fragile but also ambiguous; rather we should see these variables as a gradual endorsement and organic continuity from one end to other end. Here, in this study the score of variables branded as independent has played a rational role in creating a wave of socio-psychological and political interaction. However, the independent variables, in the study have played an ex-ante role to contribute to the structural consequent.

Table 1 presents the coefficient of correlation between socio political structure (Y) and 19 independent variables. It has been found that except the variable age $\left(\mathrm{X}_{1}\right)$, all other variables have contributed substantially towards the formation of socio-political construct (Y). The sociopolitical construct of a leader has been the resultant of interactive perception and perceptual configuration. In doing this the leaders go on exposing themselves to a score of institutions-psychic interaction, socio-political exposition, along and across the social dynamics.

Family size $\left(\mathrm{X}_{5}\right)$ has recorded a negative but significant correlation with socio-political construct (Y1). In a small size family, proper care, attention and education used to be given to the growing members. These all provide support for proper development of brain and improve the analytical skills and logics, which contributes in configuring the sociopolitical construct of a personal.

Table 1: Coefficient of correlation: Socio - political structure (Y) vs 19 Independent variables

\begin{tabular}{|c|c|c|}
\hline $\begin{array}{l}\text { Sl } \\
\text { No. }\end{array}$ & Variables & R Value \\
\hline 1 & Age $\left(X_{1}\right)$ & -0.0413 \\
\hline 2 & Community $\left(\mathrm{X}_{2}\right)$ & $0.2573 *$ \\
\hline 3 & Occupation $\left(\mathrm{X}_{3}\right)$ & $\begin{array}{l}0.4482 * \\
*\end{array}$ \\
\hline 4 & Education $\left(\mathrm{X}_{4}\right)$ & $\begin{array}{l}0.7941 * \\
*\end{array}$ \\
\hline 5 & Family Size $\left(\mathrm{X}_{5}\right)$ & $\begin{array}{l}- \\
0.2754 * \\
*\end{array}$ \\
\hline 6 & Economic Status $\left(\mathrm{X}_{6}\right)$ & -0.0752 \\
\hline 7 & Five Year Plan $\left(\mathrm{X}_{7}\right)$ & $\begin{array}{l}0.7188 * \\
*\end{array}$ \\
\hline 8 & Panchayat system perception $\left(\mathrm{X}_{8}\right)$ & $\begin{array}{l}0.5842 * \\
*\end{array}$ \\
\hline 9 & Dominance $\left(\mathrm{X}_{9}\right)$ & $\begin{array}{l}0.6231 * \\
*\end{array}$ \\
\hline 10 & Self Confidence $\left(\mathrm{X}_{10}\right)$ & $\begin{array}{l}0.6987 * \\
*\end{array}$ \\
\hline 11 & Dogmatism $\left(\mathrm{X}_{11}\right)$ & $\begin{array}{l}0.7569 * \\
*\end{array}$ \\
\hline 12 & $\begin{array}{l}\text { Authoritarianism-equalitarianism } \\
\left(\mathrm{X}_{12}\right)\end{array}$ & $\begin{array}{l}0.7819 * \\
*\end{array}$ \\
\hline 13 & Conservatism-liberalism $\left(\mathrm{X}_{13}\right)$ & $\begin{array}{l}0.6570 * \\
*\end{array}$ \\
\hline 14 & Fatalism-scienticism $\left(\mathrm{X}_{14}\right)$ & $\begin{array}{l}0.7379 * \\
*\end{array}$ \\
\hline 15 & Individualism-familism $\left(\mathrm{X}_{15}\right)$ & $\begin{array}{l}0.6959 * \\
*\end{array}$ \\
\hline 16 & Progressive reactionary $\left(\mathrm{X}_{16}\right)$ & $\begin{array}{l}0.6934 * \\
*\end{array}$ \\
\hline 17 & Political ideology $\left(\mathrm{X}_{17}\right)$ & $\begin{array}{l}0.7460 * \\
*\end{array}$ \\
\hline 18 & Election attitude $\left(\mathrm{X}_{18}\right)$ & $\begin{array}{l}0.5360 * \\
*\end{array}$ \\
\hline 19 & Alienation $\left(\mathrm{X}_{19}\right)$ & $\begin{array}{l}0.7896 * \\
*\end{array}$ \\
\hline
\end{tabular}

Table 2 presents the path analysis for deriving the direct, indirect and residual effect of antecedent variables on the consequent variable, socio-political structure (Y).

It has been found that the variable alienation $\left(\mathrm{X}_{19}\right)$ has steered the highest direct effect on the socio-political construct (Y). This variable compositionally has been dovetailed to structural dimension and so has got tremendous associational impact on the consequent character. 
Table 2: Path Analysis: Direct, Indirect and Residual Effect (Y) Socio-Political Structure Vs 19 antecedent Variables

\begin{tabular}{|c|c|c|c|c|c|c|c|c|c|}
\hline \multirow{3}{*}{$\begin{array}{l}\text { Antecedent Variables } \\
\text { Age }\left(X_{1}\right)\end{array}$} & \multirow{3}{*}{$\begin{array}{l}\text { Total Effect }(\mathbf{r}) \\
-0.0413\end{array}$} & \multirow{3}{*}{\begin{tabular}{|l} 
Direct Effect \\
-0.1000
\end{tabular}} & \multirow{3}{*}{\begin{tabular}{|l|} 
Indirect Effect \\
0.0587
\end{tabular}} & \multicolumn{6}{|c|}{ Substantial Indirect Effect } \\
\hline & & & & \multicolumn{2}{|c|}{$\mathbf{I}$} & \multicolumn{2}{|c|}{ II } & \multicolumn{2}{|c|}{ III } \\
\hline & & & & 0.0590 & $\left(X_{19}\right)$ & 0.0455 & $\left(X_{14}\right)$ & -0.0294 & $\left(\mathrm{X}_{7}\right)$ \\
\hline Community $\left(\mathrm{X}_{2}\right)$ & 0.2573 & 0.0450 & 0.2123 & 0.2034 & $\left(\mathrm{X}_{19}\right)$ & -0.1181 & $\left(\mathrm{X}_{7}\right)$ & 0.1063 & $\left(\mathrm{X}_{14}\right)$ \\
\hline Occupation $\left(\mathrm{X}_{3}\right)$ & 0.4482 & -0.1090 & 0.5572 & 0.3538 & $\left(\mathrm{X}_{19}\right)$ & 0.2661 & $\left(\mathrm{X}_{14}\right)$ & -0.2255 & $\left(\mathrm{X}_{7}\right)$ \\
\hline Education $\left(\mathrm{X}_{4}\right)$ & $0.7941^{*}$ & 0.1420 & 0.6521 & 0.5548 & $\left(\mathrm{X}_{19}\right)$ & 0.4126 & $\left(\mathrm{X}_{14}\right)$ & -0.3570 & $\left(\mathrm{X}_{7}\right)$ \\
\hline Family Size $\left(\mathrm{X}_{5}\right)$ & -0.2754 & 0.0340 & -0.3094 & -0.1652 & $\left(\mathrm{X}_{19}\right)$ & -0.1064 & $\left(\mathrm{X}_{14}\right)$ & -0.1005 & $\left(\mathrm{X}_{17}\right)$ \\
\hline Economic Status $\left(\mathrm{X}_{6}\right)$ & -0.0752 & 0.0530 & -0.1282 & -0.0861 & $\left(\mathrm{X}_{14}\right)$ & -0.0642 & $\left(\mathrm{X}_{19}\right)$ & 0.0527 & $\left(\mathrm{X}_{9}\right)$ \\
\hline Five Year Plan $\left(\mathrm{X}_{7}\right)$ & 0.7188 & $-0.3810 * * *$ & $1.0998 *$ & 0.5273 & $\left(\mathrm{X}_{19}\right)$ & 0.4082 & $\left(\mathrm{X}_{14}\right)$ & 0.2565 & $\left(\mathrm{X}_{17}\right)$ \\
\hline Panchayat system perception $\left(\mathrm{X}_{8}\right)$ & 0.5842 & -0.1450 & 0.7292 & 0.4774 & $\left(\mathrm{X}_{19}\right)$ & 0.3170 & $\left(\mathrm{X}_{14}\right)$ & -0.2977 & $\left(\mathrm{X}_{7}\right)$ \\
\hline Dominance $\left(\mathrm{X}_{9}\right)$ & 0.6231 & -0.2730 & $0.8961 * *$ & 0.4852 & $\left(\mathrm{X}_{19}\right)$ & 0.3945 & $\left(\mathrm{X}_{14}\right)$ & -0.3260 & $\left(\mathrm{X}_{7}\right)$ \\
\hline Self-confidence $\left(\mathrm{X}_{10}\right)$ & 0.6987 & 0.0670 & 0.6317 & 0.5021 & $\left(\mathrm{X}_{19}\right)$ & 0.3748 & $\left(\mathrm{X}_{14}\right)$ & -0.3264 & $\left(\mathrm{X}_{7}\right)$ \\
\hline Dogmatism $\left(\mathrm{X}_{11}\right)$ & 0.7569 & 0.0070 & 0.7499 & 0.5283 & $\left(X_{19}\right)$ & 0.3927 & $\left(X_{14}\right)$ & -0.3370 & $\left(\mathrm{X}_{7}\right)$ \\
\hline Authoritarianism-equalitarianism $\left(\mathrm{X}_{12}\right)$ & $0.7819^{* * *}$ & 0.1750 & 0.6069 & 0.5329 & $\left(\mathrm{X}_{19}\right)$ & 0.3810 & $\left(\mathrm{X}_{14}\right)$ & -0.3229 & $\left(\mathrm{X}_{7}\right)$ \\
\hline Conservatism-liberalism $\left(\mathrm{X}_{13}\right)$ & 0.6570 & 0.0660 & 0.5910 & 0.4481 & $\left(\mathrm{X}_{19}\right)$ & 0.3559 & $\left(\mathrm{X}_{14}\right)$ & -0.3093 & $\left(\mathrm{X}_{7}\right)$ \\
\hline Fatalism-scienticism $\left(\mathrm{X}_{14}\right)$ & 0.7379 & $0.4520 * *$ & 0.2859 & 0.4931 & $\left(\mathrm{X}_{19}\right)$ & -0.3441 & $\left(\mathrm{X}_{7}\right)$ & 0.2496 & $\left(\mathrm{X}_{17}\right)$ \\
\hline Individualism-familism $\left(\mathrm{X}_{15}\right)$ & 0.6959 & -0.1500 & $0.8459 * * *$ & 0.4802 & $\left(\mathrm{X}_{19}\right)$ & 0.4027 & $\left(\mathrm{X}_{14}\right)$ & -0.3231 & $\left(\mathrm{X}_{7}\right)$ \\
\hline Progressive- reactionary $\left(\mathrm{X}_{16}\right)$ & 0.6934 & 0.0400 & 0.6534 & 0.4835 & $\left(\mathrm{X}_{19}\right)$ & 0.3363 & $\left(\mathrm{X}_{14}\right)$ & -0.3029 & $\left(\mathrm{X}_{7}\right)$ \\
\hline Political ideology $\left(\mathrm{X}_{17}\right)$ & 0.7460 & 0.3100 & 0.4360 & 0.4448 & $\left(\mathrm{X}_{19}\right)$ & 0.3637 & $\left(\mathrm{X}_{14}\right)$ & -0.3149 & $\left(\mathrm{X}_{7}\right)$ \\
\hline Election attitude $\left(\mathrm{X}_{18}\right)$ & 0.5360 & 0.0310 & 0.5050 & 0.3655 & $\left(\mathrm{X}_{19}\right)$ & 0.3140 & $\left(\mathrm{X}_{14}\right)$ & -0.2882 & $\left(\mathrm{X}_{7}\right)$ \\
\hline Alienation $\left(\mathrm{X}_{19}\right)$ & $0.7896 * *$ & $0.6050 *$ & 0.1846 & 0.3688 & $\left(\mathrm{X}_{14}\right)$ & -0.3324 & $\left(\mathrm{X}_{7}\right)$ & 0.2283 & $\left(\mathrm{X}_{17}\right)$ \\
\hline
\end{tabular}

Residual Effect 0.2472 
Table 3: Regression Analysis: Socio political structure (Y) and 19 Independent causal variables.

\begin{tabular}{|l|l|l|l|l|l|}
\hline Variables & Beta & Beta $\mathbf{X}$ R & Reg Coef - B & SE of B & T Value of B \\
\hline Age $\left(\mathrm{X}_{1}\right)$ & -0.100 & 0.549 & -0.072 & 0.043 & 0.689 \\
\hline Community $\left(\mathrm{X}_{2}\right)$ & 0.045 & 1.549 & 0.209 & 0.292 & 0.716 \\
\hline Occupation $\left(\mathrm{X}_{3}\right)$ & -0.109 & -6.485 & -0.597 & 0.436 & 1.369 \\
\hline Education $\left(\mathrm{X}_{4}\right)$ & 0.142 & 14.933 & 0.526 & 1.127 & 0.466 \\
\hline Family size $\left(\mathrm{X}_{5}\right)$ & 0.034 & -1.246 & 0.203 & 0.417 & 0.486 \\
\hline Economic Status $\left(\mathrm{X}_{6}\right)$ & 0.053 & -0.534 & 0.038 & 0.047 & 0.799 \\
\hline Five Year Plan $\left(\mathrm{X}_{7}\right)$ & -0.381 & -36.402 & -1.045 & 0.560 & 1.865 \\
\hline Panchayat system perception $\left(\mathrm{X}_{8}\right)$ & -0.145 & -11.235 & -0.366 & 0.291 & 1.258 \\
\hline Dominance $\left(\mathrm{X}_{9}\right)$ & -0.273 & -22.620 & -0.987 & 0.480 & 2.056 \\
\hline Self Confidence $\left(\mathrm{X}_{10}\right)$ & 0.067 & 6.240 & 0.238 & 0.490 & 0.485 \\
\hline Dogmatism $\left(\mathrm{X}_{11}\right)$ & 0.007 & 0.702 & 0.023 & 0.556 & 0.042 \\
\hline Authoritarianism-equalitarianism $\left(\mathrm{X}_{12}\right)$ & 0.175 & 18.146 & 0.383 & 0.337 & 1.139 \\
\hline Conservatism-liberalism $\left(\mathrm{X}_{13}\right)$ & 0.066 & 5.759 & 0.183 & 0.358 & 0.511 \\
\hline Fatalism-scienticism $\left(\mathrm{X}_{14}\right)$ & 0.452 & 44.337 & 1.643 & 0.708 & 2.321 \\
\hline Individualism-familism $\left(\mathrm{X}_{15}\right)$ & -0.150 & -13.829 & -0.549 & 0.545 & 1.007 \\
\hline Progressive reactionary $\left(\mathrm{X}_{16}\right)$ & 0.040 & 3.715 & 0.047 & 0.138 & 0.343 \\
\hline Political ideology $\left(\mathrm{X}_{17}\right)$ & 0.310 & 30.760 & 0.993 & 0.379 & 2.620 \\
\hline Election attitude $\left(\mathrm{X}_{18}\right)$ & 0.031 & 2.219 & 0.032 & 0.098 & 0.325 \\
\hline Alienation $\left(\mathrm{X}_{19}\right)$ & 0.605 & 63.441 & 0.981 & 0.278 & 3.533 \\
\hline
\end{tabular}

$\boldsymbol{R} S \boldsymbol{q}=75.28 \%$,

The highest indirect effect has been routed by the variable five year plan $\left(\mathrm{X}_{7}\right)$ to imply that this variable has got huge fecundity to imbibe and beget the associational impacts of other variables while ultimately characterizing the behaviour of consequent variable.

Table 3 presents the multiple regression to estimate the effect of regression of each of the 19 casual variables on consequent variable socio- political structure(Y).

The table elicited that the causal variable alienation $\left(\mathrm{X}_{19}\right)$, fatalism-scienticism $\left(\mathrm{X}_{14}\right)$, five year plans $\left(\mathrm{X}_{7}\right)$ have exerted strong regressional impacts through their percentile contribution to the $R^{2}$ value. Of the total $R^{2}$ value 75.28 per cent, 63.441 per cent contribution has been made by the single variable alienation $\left(X_{19}\right)$. This indicates that the alienation is a basic instinct of a leader and at the same time he wants to draw upon the people as well. This can be delineated as centre periphery contradiction. The other casual variables having substantive impact on sociopolitical construct are five year plan $\left(\mathrm{X}_{7}\right)$, fatalismscienticism $\left(\mathrm{X}_{14}\right)$. The $\mathrm{T}$ values of the casual variables like dominance $\left(\mathrm{X}_{9}\right)$, fatalism - scienticism $\left(\mathrm{X}_{14}\right)$, alienation $\left(X_{19}\right)$ have been identified as significant. These variables bearing substantive and swashbuckling impact can rightly draw the alteration of social scientist while designing a training program on leadership style and pattern.

The $\mathrm{R}^{2}$ value being 75.28 per cent, it could be concluded that with this constellation of 19 casual variables 75.28 per cent of variance embedded with the consequent variables, could be explained.

The Table 4 depicts the step down regression analysis which has drifted the trivial variables and retained few variables at the last stage to imply its substantive contribution in explaining the variability embedded with the consequent variables. It has been found that a colony of six variables like age $\left(\mathrm{X}_{1}\right)$, five year plan $\left(\mathrm{X}_{7}\right)$ dominance $\left(\mathrm{X}_{9}\right)$ fatalismscienticism $\left(\mathrm{X}_{14}\right)$ political Ideology $\left(\mathrm{X}_{17}\right)$ and alienation $\left(\mathrm{X}_{19}\right)$ together, after being retained at the last stage, has amounted to the substantial explicability of variance, 73.17 percent of total variability of 75.28 percent, does rightly claim to be focused duly while a strategic intervention on leadership training is being designed. The independent variables like dominance $\left(\mathrm{X}_{9}\right)$, self-confidence $\left(\mathrm{X}_{10}\right)$, dogmatism(X11), authorianism equalitarianism (X12), conservatism-liberalism $\left(\mathrm{X}_{13}\right)$,fatalism scienticism $\left(\mathrm{X}_{14}\right)$, individualism-scienticism (X15), progressive- reactionary $\left(\mathrm{X}_{16}\right)$, political ideology $\left(\mathrm{X}_{17}\right)$, election $\left(\mathrm{X}_{18}\right)$, alienation $\left(\mathrm{X}_{19}\right) \quad$ etc can be branded as extremely soft variables that have contributed to the socio - political construct $(\mathrm{Y})$ as well as the other variables like age $\left(\mathrm{X}_{1}\right)$, community $\left(\mathrm{X}_{2}\right)$, occupation $\left(\mathrm{X}_{3}\right)$, education $\left(\mathrm{X}_{4}\right)$, economic status $\left(\mathrm{X}_{6}\right)$, five year plan $\left(\mathrm{X}_{7}\right)$, panchayat system $\left(\mathrm{X}_{8}\right)$ can well be branded as quasi quantitative variables because of their direct contribution to the structural entity of socio - political construct (Y). 
Table 4: Step down Regression for Elimination of Trivial Variables Socio- political structure (Y) vs 19 Independent variables.

\begin{tabular}{|l|l|l|l|l|l|}
\hline Variables & Beta & Beta XR & Reg coef - B & SE of B & T Value of B \\
\hline Age $\left(\mathrm{X}_{1}\right)$ & -0.117 & 0.658 & -0.084 & 0.039 & 2.153 \\
Five Year Plan $\left(\mathrm{X}_{7}\right)$ & -0.325 & -31.969 & -0.892 & 0.441 & 2.022 \\
Dominance $\left(\mathrm{X}_{9}\right)$ & -0.276 & -23.503 & -0.996 & 0.428 & 2.330 \\
Fatalism-scienticism $\left(\mathrm{X}_{14}\right)$ & 0.428 & 43.146 & 1.554 & 0.525 & 2.958 \\
Political Ideology $\left(\mathrm{X}_{17}\right)$ & 0.370 & 37.712 & 1.184 & 0.316 & 3.744 \\
Alienation $\left(\mathrm{X}_{19}\right)$ & 0.685 & 73.956 & 1.111 & 0.183 & 6.072 \\
\hline $\boldsymbol{R} \mathbf{S q = 7 3 . 1 7 \% ,}$
\end{tabular}

\section{Conclusion}

The socio - political construct does manifest a person's philosophy of life and outlook about society and political issues. Accordingly, they act and respond to social eventualities and try to organize the people or group in the framework of his ideology for achieving some goals related to the development of people and the nation. People choose their leader because of his political skills. It is therefore, important that the conventional leadership training need to be modernized by incorporating more political and behavioural training in terms of heterophilous personality character. Thus for better and effective construction of leadership and unleashing of their function, we need to have a focused and effective training viz a viz motivational interventions.

\section{Reference}

Adhikary MM (1982) Structure of Rural Leadership in a District of West Bengal, Unpublished Ph. D. Thesis, Department of Agricultural Extension. Faculty of Agriculture, BCKV, Mohanpur, West Bengal.

Singh CP (1991) Dimensions of rural leadership. Dimension of rural leadership.p.164

Zamani GH and Karami E (2006) Rural leadership and sustainable agriculture: criteria for recruiting leaders. Journal of food, agriculture and environment: p.228-234. 